\title{
Framing Political Violence: Success and Failure of Religious Mobilization in the Philippines and Thailand
}

\author{
ALEXANDER DE JUAN ${ }^{\mathrm{a}}$ AND \\ ANDREAS HASENCLEVER ${ }^{\mathrm{b}}$ \\ ${ }^{\mathrm{a}}$ German Institute for Global and Area Studies, Neuer Jungfernstieg 21, \\ 20354 Hamburg, Germany \\ ${ }^{\mathrm{b}}$ Institute for Political Science, University of Tuebingen, Melanchthonstr. 36, \\ 72074 Tuebingen, Germany
}

\begin{abstract}
How do religious civil wars evolve? Many violent conflicts are fought between groups of different faiths. The paper argues, however, that religious differences rarely directly lead to conflict onset. Rather, the apparent religious dimension of many civil wars is a consequence of successful religious framing. Political and military leaders offer religious interpretations designed to legitimize the use of force and to mobilize believers to violent action. Such framing processes can be more or less successful, depending inter alia on the authority of the political and religious leadership, on the coherence and appropriateness of the frames, on the existence of persuasive counter-frames, and on the availability of communication infrastructures that allow for effective dissemination of religious frames. Comparing violent conflicts in the Philippines and Thailand, the paper shows that religious mobilization can fail along the theoretically predicted lines.
\end{abstract}

\section{INTRODUCTION}

Religions have a bad reputation in the western public. Many media reports suggest that fanatic believers use deadly force to spread their faith in such places as Afghanistan, the Central African Republic, Iraq, Mali, Nigeria, Palestine, Sri Lanka, Syria, or Thailand. At first glance, these examples seem to confirm primordial interpretations of religious violence: irreconcilable dogmatic differences turn religious communities against one another and often incite unconstrained confrontations over sacred issues. ${ }^{1}$ The majority of quantitative studies, however, paint a different picture. Religious differences as such are rarely at the heart of religious civil wars. ${ }^{2}$ To bridge this gap between media observations and comparative analyses, we argue that 'religious framing' plays a central role for the emergence of religious civil wars. From such a perspective, religion is likely to 
contribute to violence when rational political leaders successfully frame conflicts in religious terms.

While there is little doubt that armed conflicts can develop their own dynamic, we believe that without effective coordination and strategic leadership, militant movements cannot be sustained in the long run. ${ }^{3}$ Moreover, mobilizing fighters and maintaining societal support requires more than just material resources and logistical planning. In most cases, there must also be a strong consensus within the conflict party and its social environment about who they are, what they are fighting for, and whom they are confronting. ${ }^{4}$ These collective justifications so-called 'Collective Action Frames' do not develop spontaneously. Rather, they must be actively disseminated and sustained.

Thus, in our understanding, elites play a decisive role in violent conflicts. On the one hand, they plan and coordinate combat operations. On the other hand, they have to convince their constituencies of the necessity of the armed struggle. Consequently, material conditions such as opportunity structures or horizontal inequalities are not sufficient to account for the onset and the duration of armed conflicts. Strong discourses calling for the use of force are equally important. If elites fail in providing such framing, mobilization and rebellion tend to break down. We argue that religious civil wars evolve when elites successfully frame conflicts in religious terms.

To underpin this argument, we will first summarize the state of the art on the role of religion in armed conflicts. We show that common theoretical approaches struggle to convincingly explain religious violence. As a theoretical alternative, we develop an elite-oriented concept of religious framing, drawing on the literature on social movements. Finally, we will illustrate the importance of political elites and their attempts at religious framing by comparing the conflicts in the Philippines and Thailand. The empirical part of the paper shows that observable differences across both cases can plausibly be explained with an actor-oriented framing model as developed in the paper.

\section{THEORETICAL APPROACHES AND EMPIRICAL FINDINGS}

There are a number of strong theoretical arguments as to why religious differences should raise the risk of conflict onset and increase both conflict intensity and conflict duration. ${ }^{5}$ First of all, religions have the potential to transform secular conflicts over power, welfare, and recognition into a cosmic struggle between good and evil. Under these conditions, the conflict issues turn indivisible, the related positional differences are made into absolutes, and compromise is no longer an option for the belligerents. A clear distinction between us and them emerges together with a corresponding strong tendency to demonize the opponent as one who cannot be trusted and who has to be defeated with all available means. Second, the combatants see themselves as holy warriors. They are fighting for the salvation of the world, and they are willing to accept great hardship in return for eternal peace. Because they know that heaven is on their side, 'holy warriors' refuse to give in. They expect to 
win even if the actual situation is grim. In fact, as Michael Horowitz has pointed out, 'religion is a powerful motivator.' Third, religions provide the combatants with important institutional resources, which can be used to sustain the confrontation and to mobilize the faithful into action. ${ }^{7}$ Overall, religion not only gives the conflict parties extraordinarily strong reasons and the necessary resolution to start and sustain an armed conflict, but also affects their organizational capacities and adds significant resources to the fighting. ${ }^{8}$

Despite the strong theoretical arguments for a close religion-conflict-nexus, the empirical record is mixed at best. As Jonathan Fox among others has shown, the proportion of religious conflicts increased since the end of the Cold War. Since the start of the new millennium, religious conflicts have made up more than half of all civil wars. ${ }^{9}$ At the same time, however, the absolute number of religious conflicts stagnated or even decreased, a fact which corresponds to the global trend in the occurrence of armed conflicts and civil wars. This is surprising since we have been witnessing a global resurgence of religion over the last 30 years. Moreover, straightforward empirical evidence for a major impact of 'religious identity incompatibilities' or 'religious issue incompatibilities' on the onset of armed conflicts is difficult to establish. ${ }^{10}$ Most scholars agree that armed conflicts mainly result from secular differences. In this context, religion may play a role in the constitution of group identities. But this seems to increase the risk of conflict onset only if religious identities overlap with other collective identities. ${ }^{11}$ At the same time, Nils-Christian Borman and his colleagues found that "linguistic differences are more strongly associated with conflict than religious cleavages. ${ }^{12}$ According to the authors, this points to the mobilizing power of nationalism as one which still outperforms religious markers. Similar results are provided by Uwe Waagschal and his co-authors, who observed that linguistic heterogeneity has a much stronger impact on conflict onset than religious heterogeneity. ${ }^{13}$ Taken together, these findings point to the importance of collective identities for the onset of armed conflict. Religious identities, however, do not seem to be more virulent in this regard than class, ethnicity, or nationality..$^{14}$

Similarly, the findings on the intensity of religious conflicts are not as clear-cut as could have been expected. While Jonathan Fox and Monica Toft report some evidence in support of a religion-severity nexus, their conclusions result from bivariate analyses only. ${ }^{15}$ The multivariate studies of Bethany Lacina and Ragnhild Nordås, by contrast, could not detect any significant intensity difference between religious und non-religious armed conflicts. ${ }^{16}$ Susanna Pearce even found that between 1946 und 200124 per cent of all secular conflicts in her sample reached the highest intensity levels while only 20 per cent of all religious conflicts did. ${ }^{17}$ Similarly, Frances Steward argues that among the incidents of mass killings since 1956 'there is no single case of religion alone, but religion combined with ethnicity/ nationality played a role in four cases out of the $16 .{ }^{18}$

Empirical findings on the religion-conflict-nexus are also mixed when it comes to conflict duration. Monica Toft reports that "whereas nonreligious civil wars last on average 76 months, religious civil wars last 103 months. ${ }^{19}$ This difference is not 
significant, however, and what is even more puzzling: conflicts in which religion is a peripheral issue last on average 28 months longer than civil wars in which religion is a central issue. Following Toft's own reasoning, the opposite should be the case. According to a study by Tanja Ellingsen, religious differences impacted positively on the duration of armed conflicts only after the Cold War. During the Cold War, the opposite holds true. ${ }^{20}$ Andrej Tusicisny, by contrast, found "no statistically significant relationship between civilizational difference and duration of conflict whether we consider the post-Cold War period or the whole period 1946 2001.' ${ }^{21}$ With a slightly different focus, Paul Collier and his colleagues also could not detect any particular impact of religious fractionalization on conflict duration while ethnic fractionalization was relevant. ${ }^{22}$ Finally, data provided by Isak Svensson suggest that among the 20 conflicts with the longest duration, none was about religious incompatibilities. ${ }^{23}$

Up to now, only the findings on conflict termination largely fit with the outlined theoretical expectations. As demonstrated by Isak Svensson, belligerents are very unlikely to reach a negotiated settlement in conflicts over religious issues. ${ }^{24}$ In the clear majority of cases, these conflicts come to an end by military victory only. According to Isak Svensson, this follows from the indivisibility of religious demands which prevent the belligerents from making the necessary concessions. But even though the tendency of religious armed conflicts to continue until one side wins is strong, there were 'holy wars' such as those in Indonesia or on the Philippines in which the belligerents were able to stop the fighting by 'desacralizing' their confrontation. ${ }^{25}$

In our understanding, the mixed findings on the religion-conflict-nexus so far point to 'the ambivalence of the sacred' as outlined by Scott Appleby among others. ${ }^{26}$ Sometimes religions do play a crucial role in the motivation of armed conflict while in other cases they might even promote conflict transformation and peace making. Consequently, it is not religion and religious differences as such that increase the risk of conflict onset and that impact on conflict intensity and conflict duration but interpretations of the sacred as offered by political and religious elites and as accepted by their constituencies. What we have to account for is why religious differences translate into effective mobilization and escalation in some cases but not in others.

\section{THE ROLE OF ELITES IN RELIGIOUS CIVIL WARS}

Civil wars do not happen spontaneously, and without strategic leadership rebellions can easily be defeated. On the one hand, collective violence must be organized. Troops have to be recruited, trained, and deployed. They must be provided with food, weapons, and transportation. Attacks have to be planned, reactions of enemy forces have to be anticipated, and armed forces must be moved accordingly. On the other hand, collective violence must be legitimized. Larger groups cannot sustain armed conflicts without so-called 'collective action frames.' In the literature on social movements, this term refers to 'action-oriented sets of beliefs and meanings 
that inspire and legitimate the activities and campaigns of a social movement organization. ${ }^{27}$ Collective action frames are considered vital for mobilizing a constituency, winning support of neutral individuals, and demobilizing antagonistic groups. Such effective collective interpretations only evolve if they are proposed and spread centrally. Consequently, elites matter not only in organizational terms but also for providing mobilizing frames. ${ }^{28}$

In this article, we argue that religion might be a valuable but always contested tool in all steps of the framing process. The first step consists of diagnosing the nature of the conflict and determining the identity of the conflict parties. Religious messages might be used to identify deprivation and the violation of sacred rules. Additionally, religion might help to unite otherwise fragmented groups by putting the faithful against a common enemy who is portrayed as a force of evil determined to destroy a sacred community. ${ }^{29}$ In a second step, appropriate reactions to the identified problems are articulated. Peaceful solutions should be portrayed as being hopeless, thereby highlighting the need for violent action. In line with arguments presented above, we believe that conflicts framed in religious terms can easily be excluded from any peaceful conflict resolution that is based on compromise. The third function of a collective action frame is to motivate people to act. It is one thing to identify problems and to suggest possible strategies to solve them, it is quite another to move people to risk their lives in battle against the enemy. Religion has often proved useful for moving constituents 'from the balcony to the barricades' by promising otherworldly rewards and punishments. ${ }^{30}$

Given the suitability of religious frames for the mobilization of political violence, political leaders time and again try to embed economic or political conflicts in a religious context and to present an armed confrontation as a necessary corollary of the religious beliefs of the group. Contrary to simple instrumentalist arguments, however, we argue that these efforts can be more or less effective. It is therefore crucial to learn more about the conditions of successful religious framing.

\section{SUCCESS FACTORS OF RELIGIOUS FRAMING}

Frames are always embedded in specific political and cultural contexts, which influence their motivational effectiveness. ${ }^{31}$ Successful attempts at mobilizing groups will score high on a number of structural conditions that determine the frame resonance with the audience. First, religious frames will not fit with an atheistic public. They presuppose an audience that shares a particular, religiously inspired world view and that attributes a high relevancy to sacred traditions. Second, successful frames must be empirically credible and central to the audience's values. Frames that lack strong references to shared experiences and moral convictions of a community will likely fail. The mobilization of a group for collective action presupposes that most members are convinced that they have to act under given conditions in a specific way to pursue common interest and to promote shared values. Third, the diagnosis of a problem, the proposed solution, and the required activities must make moral, practical, and personal sense to the audience. 
Consequently, attempts at mobilizing people with religious calls for violence will be particularly promising when the parties to a conflict belong to different religious communities and when the faithful are experiencing a subjective threat to their religion or their religious identity. ${ }^{32}$

The fit of a frame with structural factors, however, is often not enough to mobilize collective action. The credibility of the frame makers, their capacity to disseminate a message as well as the power of competing frames are equally important. ${ }^{33}$

Credibility depends on the professional reputation of the frame makers, on their institutional authority, and on his or her personal integrity. In a religious context, this means that an interpreter is recognized as a person with a profound knowledge of the holy texts and religious traditions. ${ }^{34}$ Consequently, religious elites supporting religious interpretations of violent conflicts can effectively contribute to increasing frame effectiveness. When referring to religious elites, we mean individuals who are accepted by the believers as legitimate interpreters of religious dogmas, such as imams, priests, gurus, or rabbis. Such religious interpreters should be part of a larger community of interpreters and should ideally occupy a leading and respected position within this community. Finally, religious interpreters will lose credibility if they are perceived to act out of personal interest and not for sacred reasons. In most cases, believers only accept religious interpretations from elites that they view as 'apolitical' in the sense that their actions are based on a firm and unchangeable canon of spiritual values and not on personal interest. ${ }^{35}$

Frame makers must also be able to reach their audience in a technical sense. The concept of framing has been developed in the context of western social movements. Accordingly, the necessity of functional communication structures is often neglected. However, in many states, the dissemination of mobilizing frames cannot be taken for granted. Brent Hierman, for instance, shows that the formation of a broad Muslim resistance movement in Xinjiang against state repression is made next to impossible by the geographical situation. ${ }^{36}$ The effective dissemination of collective action frames is hindered by the enormous size of Xinjiang and its lack of infrastructure. This has effectively prevented the spread of a common mobilizing conflict interpretation among the people. Consequently, again, backing by religious elites is essential as they can more effectively and more credibly draw on religious networks and infrastructures such as houses of worship and are often closely linked to believers through regular contacts in religious services, prayer groups, or social welfare activities. ${ }^{37}$

Finally, the success of religious framing is not only dependent on their absolute but also on their relative persuasive power as compared to competing frames. Frames always risk being outperformed by counter-frames. ${ }^{38}$ Where religious framing of conflicts is challenged by competing religious interpretations questioning the religious nature of the respective conflict, the actual outcome will be dependent on the relative credibility and presence of the competing elites. For example, strong coalitions of religious elites on various hierarchical levels of religious communities may easily discredit competing religious interpretations disseminated by single religious elites or individual political actors. ${ }^{39}$ Analyzing frame contests within the 
Salafi community, Quintan Wiktorowicz shows how the followers of a radical interpretation of Islam which promoted violence came into competition with a reformist branch. ${ }^{40}$ Each party claimed unique authority to interpret Islam and tried to defend their positions among the population. The parties stressed their own knowledge and integrity while questioning their competitors on the same grounds.

The following sections illustrate the explanatory power of this framing approach for temporal dynamics of violent conflicts in Thailand (1967 1983) and the Philippines (1972 1995).

\section{VIOLENT CONFLICTS IN THAILAND AND THE PHILIPPINES}

The conflicts in Thailand and the Philippines share many important similarities. In both cases, a regionally concentrated Muslim minority has been in opposition to a central government dominated by the respective majoritarian religious group Christians in the case of the Philippines and Buddhists in the case of Thailand. Both minority groups experienced substantial economic and political discrimination as well as attempts at forced cultural integration, which eventually led to the creation of various armed movements. In the mainly Muslim provinces of both countries, Islam had experienced a societal revitalization in the 1950s and 1960s. These processes coincided with a global trend of 'religious resurgence' highlighted in previous research. ${ }^{41}$ Local processes of revitalization were further strengthened by an increasing number of youths receiving international financial support for religious studies in the Middle East, India, and Pakistan and returning to their home communities as religious teachers and imams. Until the 1970s, however, religion had not been an integral part of the legitimizing ideology of any rebel organization. This changed later on, when important external allies distanced themselves from the rebellion and societal support dropped dramatically following political concessions to the respective minority groups by the national governments. Under increasing pressure, rebel movements in both countries tried to capitalize on the religiosity of their Muslim constituencies and started to use explicit religious frames to mobilize the population.

Despite the many similarities of these two cases, there is one crucial difference: the rebels in the Philippines successfully used their religious interpretations of the conflict to mobilize support while rebels in Thailand did not. To explain these distinct outcomes, we will use the previously outlined elite-centered model of religious conflict. In our understanding, the rebels in the Philippines were able to develop and spread a convincing religious frame while the rebel leaders in Thailand tried but failed to do so. In line with the theoretical arguments presented above, our central thesis is that successful framing by the Philippine rebels can be traced back to a higher level of credibility, a more effective dissemination of religious frames among the people, and a lower level of framing competition. Thus, while structural preconditions for effective religious mobilization were promising in both cases, the distinct framing capabilities of the respective elites explain the varying framing outcomes. 
After a short presentation of each conflict, we will outline how collective action frames of rebel groups in the Philippines and Thailand have changed over time focusing on the rationalist reasons behind the rebels' change in strategy as well as its consequences on the course of the rebellion. Thus, our attention will be focused on the period from the beginning of the 1970s to the end of the 1980s. The following section will discuss the determinants of distinct levels of framing success across both cases. We are aware that the design of our case study does not allow us to rule out that political and economic factors drove the course of the conflicts. We argue, however, that political and economic factors alone cannot sufficiently explain why the two conflicts developed in such distinct ways. In our understanding, it is only possible to provide a satisfactory explanation for these differences by looking at the success of elites' framing attempts. The conclusion will provide for a discussion of our findings in the light of alternative explanations.

\section{Background to the Conflict}

Interreligious relations have traditionally been rather harmonious in the southern Philippines. Violent conflict among religious communities was rare. This changed when the government in Manila began to resettle Christians from the northern to the southern regions of country, accompanied by attempts at advancing the 'Philippinization' of the Muslim population. This process made the Muslims a minority in their traditional homeland. Most influential economic and bureaucratic positions were taken over by Christians. As a result, inter-group conflicts became more frequent and more intense. Violence broke out at the local level in the 1950s between autochthon groups and the migrants from the north. ${ }^{42}$ The conflict escalated after the declaration of martial law in 1972 when the Moro National Liberation Front (MNLF) began its armed struggle against the government. Both a military stalemate and international pressure forced the regime to enter into the so-called Tripoli Agreement of 1977. This, however, did not bring an end to the violence in the southern Philippines. Internal opposition to the peace agreement resulted in a split of the MNLF in 1978, leading to the creation of the Moro Islamic Liberation Front (MILF). As the importance of the MNLF declined over the years, MILF became the central rebel organization. In 1996, a marginalized and demoralized MNLF signed a peace treaty with the government. The MILF, on the other hand, continued its violent struggle. The following nearly two decades saw various cycles of violent escalation and de-escalation including numerous failed attempts at ending the conflict in a peaceful way. Finally in 2014, the government of the Philippines and MILF signed the Comprehensive Agreement on the Bangsamoro (CAB) formally ending the conflict, while smaller rebel factions continue their fight against the government.

The conflict in southern Thailand began under similar circumstances. ${ }^{43}$ Until the end of the 19th century, interreligious relations between Muslims and Buddhists were mostly peaceful. It was only at the beginning of the 20th century when the government in Bangkok began restricting the traditional autonomy of the region that 
tensions began to rise. As a consequence of the national process of centralization, many local Muslim elites lost their power positions to Buddhist government loyalists and began to work towards the secession of their region and its integration into neighboring Malaysia. The lack of self-determination for Muslims, the marginal economic development of the region, a state-sponsored policy of forced cultural assimilation as well as a state-sponsored resettlement program all contributed to increasing tensions between the government and the Muslim population. Shortly after World War II, secessionist demands became stronger and won broad societal support in the south, leading the government in Bangkok to declare a state of emergency. In 1948, the first Muslim rebel movements were formed. Among them, PULO (Patani United Liberation Organization), BNPP (Patani National Liberation Front), and BRN (National Revolutionary Front) were the most influential ones. Their guerilla activities climaxed towards the late 1960s and mid-1970s. However, in the following years the rebels lost much of their military strength and support from among the population. ${ }^{44}$ In the early 1980s, the national government actively promoted the economic development of the south, supported the public participation of Muslims, and created an amnesty program, all of which allowed the rebellion to come to an end by the mid-1980s ${ }^{45}$ The conflict saw some rather limited escalation in the years 2003 and 2013 without, however, culminating into an actual organized rebellion.

\section{From Ethnic to Religious Framing}

The first modern autonomy movement in Mindanao came into existence in 1967, founded by the former governor of the province, shortly after he had lost his political position. Although the Muslim Independence Movement's manifesto contained some religious references, it was primarily a list of political and ethnic objectives. To win the support of Christians in the region, the movement's name was later even changed to the 'Mindanao Independence Movement. ${ }^{46}$ Similarly, the earlier discourse of the MNLF was primarily of an ethno-nationalist nature. The founding members of the movement mostly came from left-leaning student groups. In accordance with their members' backgrounds, the MNLF interpreted the conflict in a primarily nationalist way. Aside from their demands for autonomy or secession, they also called for a fair distribution of land and an end to discrimination by the state. ${ }^{47}$

Throughout the second half of the 1970s and the early 1980s, however, the MNLF's ethno-nationalist discourse was supplanted by a radical Islamic interpretation of the conflict. Such religious frames significantly gained in importance when the MILF was founded in 1984. Islam became the central mobilizing force of the separatist movement. ${ }^{48}$ The MNLF has emphasized Islam as one element of the local culture among others. Under the MILF, it became the central lens through which the conflict was interpreted: "All Mujahideen under the MILF adopt Islam as their way of life. Their ultimate objective in their Jihad is to make supreme the WORD of ALLAH and establish Islam in the Bangsamoro homeland. ${ }^{49}$ While the creation of an independent state had been the primary 
objective of the MNLF, independence was reduced to a secular means to a religious end: the spread of Islam and the realization of god's will. The structure of these religious frames can be illustrated with statements of the long-time MILF leader, Hashim Salamat. His calls for violence are based on a strict Manichean world view, from which comes a clear and unmistakable separation of in-groups and out-groups: 'Either you are with Allah, His Messenger and the believers along with the Global Islamic Revival and Renaissance, or with the enemies of Allah' ${ }^{50} \mathrm{He}$ explains that the mere absence of an Islamic state, ruled by religious authorities, is equivalent to a complete ignorance of holy law. As a consequence, violent Jihad appears to be the only appropriate reaction to realize the MILF objectives.

Similar to the Philippines, the first autonomy movements in Thailand were ethno-nationalist in nature and paid little attention to religious issues. GAMPAR (Gabungam Melayu Pattani Raya Greater Pattani Malayu Association), founded in 1940, was led by disempowered traditional elites and featured an ethnic Malayan agenda. ${ }^{51}$ The group's central objectives were the unification of all Malayan regions, the improvement of local living conditions, and the advancement of Malayan education and culture. Although religious leaders played an important role in most rebel organizations, the conflict was predominantly framed in Malayan nationalist terms. Even when the respected and influential religious leader Haji Sulong made his famous demands to the government in 1947, he focused primarily on the right of self-determination of the Malayans and less on religious elements.

It was only in the late 1970 s that rebel groups began to emphasize their struggle for the protection of Islam to win regional and international recognition and support. $^{52}$ This transformation can be exemplified in the case of the PULO, one of the largest and most influential organizations. Its original objective was explicitly secular. It focused on the struggle for the liberation of all the people of Pattani, regardless of their religion. Over the course of the conflict, its objectives changed. In an analysis of PULO's pamphlets by Chaiwat Satha-Anand, one can clearly identify the elements of religious framing as sketched above..$^{53}$ The internal unity of all Muslims is stressed, with a clear disassociation from the Buddhist population: 'We follow Allah while they follow Buddhism which reveres the Buddha image. We pray and fast while they do neither.' ${ }^{54}$ The pamphlets also include selectively chosen passages from the Koran that underscore the superiority of Islam over Buddhism and illustrate the responsibility to fight the non-believers ('Fight those who believe not'). Those Muslims that refused to use violence were denounced as traitors. ${ }^{55}$ The increasing importance of Islam in the rebel movement is also mirrored in the naming of separatist organizations. Former members of the BNPP founded the United Mujaheddin Front of Pattani (BBMP) and the BNPP renamed itself into Islamic Liberation Front of Pattani (BIPP).

\section{Consequences of Frame Transformation}

In the 1970s, the MNLF was the primary rebel organization in the Philippines and mobilized between 10,000 and 30,000 active members. ${ }^{56}$ However, several studies 
emphasize that the movement's ideology barely reached the masses. ${ }^{57}$ Instead, popular support for the MNLF mainly resulted from the abuses of power by the government and its discriminatory policies against the South. Additionally, the leadership's authority was dependent on its access to foreign supplies of weapons and military training. As a consequence, the strength of the movement considerably weakened with the decline of foreign support after the Tripoli Agreement and with the improvement of diplomatic relations between the Philippines and Malaysia. At the same time, new state-sponsored programs served to reduce inequalities and injustices in the south, which led to a decline of discontent among the population. ${ }^{58}$ Along with an increasing disillusionment with the MNLF, this led more and more Muslims to abandon the rebellion. ${ }^{59}$

It was not until the MILF was founded that the rebels were able to win broad societal support with a new, radical religious agenda. The MILF was less dependent on foreign support than the MNLF due to the fact that it enjoyed strong local backing from the start. ${ }^{60}$ The MILF was perceived by the Muslim population as a Muslim army, which acted in the interest of the people. Across the region, the MILF received religious donations. ${ }^{61}$ By 1986, it was apparent that the MILF was capable of substantial and sustained mobilization. Their calls for participation in a three-day prayer demonstration were followed by 50,000 to 100,000 people every day. At the end of the 1990s, MILF's troops were estimated to be between 10,000 and 30,000 men strong. ${ }^{62}$

At the beginning of the 1980s, the rebel movement in Thailand was confronted with similar problems as the one in the Philippines. Its focus on Malayan identity had for many years allowed for access to support from strong political forces in neighboring Malaysia. However, as Malaysia and Thailand intensified political and economic cooperation, external funding dried up. ${ }^{63}$ Libya's waning interest in the conflict had similar consequences. ${ }^{64}$ At the same time, economic and cultural concessions made by the Thai government contributed to effective demobilization of many Muslims in the south.

The rebels' strategic response to these developments mirrors the one by its Philippine counterparts. Islam became the central discourse of the armed movement. In stark contrast to the Philippines, however, the rhetorical turn from ethnic to religious framing did not translate into increasing local support. Quite to the contrary, the rebel groups became increasingly fragmented in the late 1970s and early 1980s. While PULO was able to mobilize approximately 70,000 Malayans for demonstrations in Pattani in the mid-1970s, their armed troops totaled only 200 to 600 soldiers in $1982 .{ }^{65}$ Considering the political situation at the time such weak support is striking. After the abrupt end of the short-lived democratic phase from 1973 to 1976 , Muslims in the country were particularly angry about the new autocratic regime.$^{66}$ Nonetheless, the rebel groups were clearly not able to convince more than a small part of the population to actively support their cause.

To the best of our knowledge, there are no reliable time-series fatalities data that would allow for a comparison of changing intensities of violent conflicts in Thailand and the Philippines. As an alternative, we draw on violent events data provided by 
the Global Data on Events, Location and Tone (GDELT) dataset that is based on news reports from international news sources (Leetaru and Schrodt 2013). It provides information on the exact date as well as on the location of the respective action. We filtered events using the original Conflict and Mediation Event Observations (CAMEO) codes, limiting the subset to events that can reasonably be associated with lethal force such as 'Conventional military force' or 'Fight with small arms and light weapons.' From the original global dataset, we have created a subset of all events that took place within provinces with substantial Muslim population in Thailand and the Philippines. ${ }^{67}$ The following figures visualize total numbers of violent events per year in both countries for the first ten-year period included in the GDELT dataset (Figure 1).

The illustration shows a similar evolution of the number of recorded violent events for both countries from 1979 throughout 1983. From 1984, however, violence seems to increase substantially in the Philippines, whereas it diminishes further in Thailand. A direct comparison of absolute event counts across both countries is problematic due to differences in population sizes and media landscapes. Nonetheless, we believe that a comparison of the more general patterns of the conflicts lends support to our argument that the 1980s saw a substantial divergence of conflict dynamics that coincides with changing framing strategies in both rebel movements. The following section proposes an explanation for these distinct conflict trajectories despite similar strategic choices by rebel movements in Thailand and the Philippines.

\section{REASONS FOR THE VARYING DEGREES OF FRAMING EFFECTIVENESS}

Returning to the framing approach as sketched above, we believe that structural success factors alone cannot explain the variance in framing effectiveness between the two countries: In both cases, regional, economic, and ethnic cleavages clearly

FIGURE 1

GDELT VIOLENT EVENT COUNTS, 1979-1988

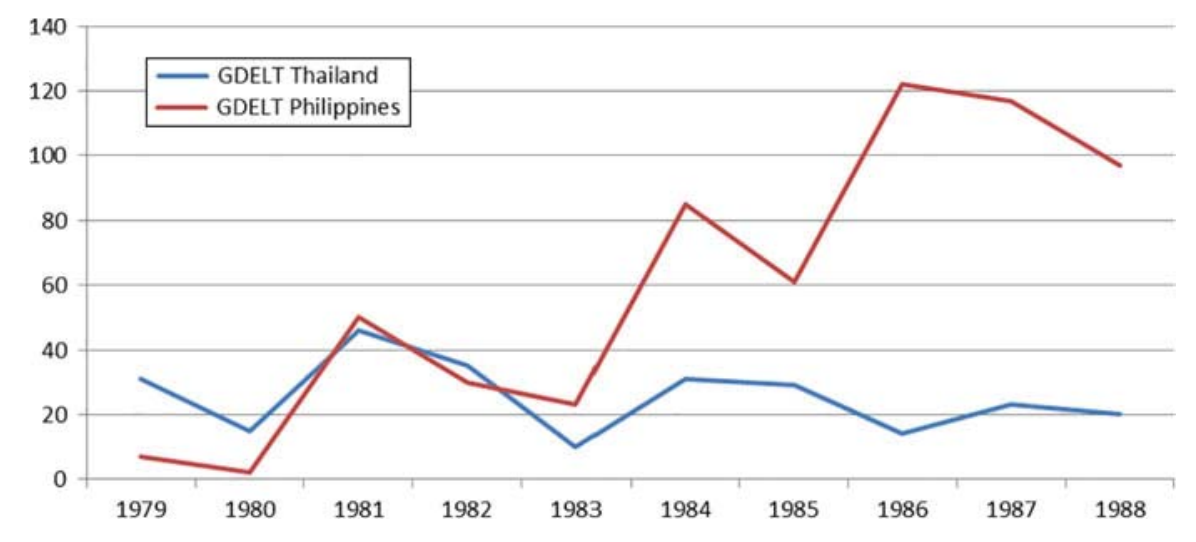


overlap with religious ones. Both communities look back at long histories of conflict with the central governments, providing for a fertile ground for religious framing of the more recent struggles for independence. Moreover, both religious communities experienced a general revitalization of Islam in the 1950s and 1960s as well an increasing salience of religious identities in light of perceived existential threats from each country's central governments. Therefore, we will focus on aspects related to the effectiveness of framing processes to explain the distinct courses of the conflicts in the Philippines and Thailand: the MILF's higher level of credibility, more successful dissemination of religious frames among the Philippine population, and lower exposure to effective framing competition.

\section{Frame Credibility}

In the 1950s and 1960s, thousands of young Muslims from the Philippines traveled abroad for Islamic studies at foreign universities. After returning home, many of these new religious scholars joined the rebel movement to fight the government, the traditional feudal structures, and the local 'folk Islam.' ${ }^{68}$ Large segments of the population saw these young scholars as religious specialists because they had studied at distinguished foreign universities. This enabled them to convincingly spread the message that the policies of the government were opposed to core teachings of the Islam and that the ulama had an obligation to resist the infidels. ${ }^{69}$ In fact, young clerics played an important role in the recruitment, organization, and ideological instruction of the rebel fighters and supporters. ${ }^{70}$ Moreover, the rebels were not only supported by local clerics but also by more widely respected central religious authorities of the various ethno-linguistic groups which considerably increased the authority of the religious framing. ${ }^{71}$ Finally, the MILF's credibility was further strengthened by the pious observance of religious conventions. In the MILF camps, smoking and drinking alcohol were forbidden; the Sharia was implemented in areas occupied by the MILF. ${ }^{72}$

The rebel movements in Thailand did not possess similar religious backing to bolster the credibility of their religious frames. From the beginning of the conflict, the traditional Islamic clerics, the so-called 'Tok gurus,' were deeply divided over whether to support or to oppose the modernization program of the central government. ${ }^{73}$ Some 'tok gurus' who feared social and political marginalization sided with the rebels, while others concluded that their best bet would be to re-organize the religious school system and to accept national curricula in exchange for state funding. ${ }^{74}$ Thus, support for the rebels' religious frames was limited to a subset of local religious leaders. Considering that the religious authority of the 'Tok Gurus' was confined to their respective local communities, the rebel movement would have needed the broad support of religious teachers if they wanted to reach large parts of the population. The rebels were also not able to compensate for the lack of local support with the help of recognized regional or national leaders. The centralized structures of the ulama had been integrated into the state's public bureaucracy with the 1945 Patronage of Islam Act. ${ }^{75}$ As a consequence, the rebel 
movement did not possess a sufficiently broad-based and credible mouthpiece to support its religious rhetoric.

\section{Dissemination of Frames}

Early on, the MILF invested considerable resources into the dissemination of its religious interpretation of the conflict. Especially in its early days, it used substantial parts of its funds for activities aiming at strengthening the Islamic identity and religious awareness of the population. Thus, they provided support to a network of local mosques and religious schools in order to create a solid foundation for the struggle for independence. ${ }^{76}$ The MILF also invested in consolidating its religious frames among its combatants. Each unit was assigned a spiritual leader who propagated MILF's religious interpretations of the conflict. ${ }^{77}$ Religious seminars were also held regularly in the MILF military camps. ${ }^{78}$ These activities enabled the MILF to create an ideological infrastructure for the sole purpose of conveying its religious messages directly to active fighters and the Muslim population at large.

The rebel movement in Thailand did not actively work towards the dissemination of its religious conflict interpretation to the same extent as rebels in the Philippines. According to Wan Kadir Che Man, rebel leaders interpreted the participation of a large part of the local population in the 1975 demonstrations as a sufficient sign of broad-based local support. ${ }^{79}$ As a result, they did not invest their meager resources in generating support. Furthermore, they did not have comparable communication structures at their disposal. In their early years, the BNPP and the BRN had tried to infiltrate religious schools and to use allied religious teachers in recruiting soldiers. However, over the course of the 1960s (most of the), schools and mosques came under state control and were thus removed from the reach of the rebels. ${ }^{80}$ Moreover, the rebel organizations themselves were too weak to effectively spread religious interpretations of the conflict. Their central committees were located abroad and their control over local combat units was weak. ${ }^{81}$ This decentralized organization prevented any attempts at effective dissemination of a coherent religious ideology.

\section{Framing Contests}

The religious framing of the rebels in the Philippines was further strengthened by the absence of persuasive counter-frames. While the traditional elites in the South ('Datu') and the closely associated traditional ulama had a clear interest in challenging the religious interpretations of the rebels, they were unable to do so. For large segments of the Muslim population, they were too deeply involved in defending the feudal status quo in rural areas. Moreover, they were considered local allies of the Philippine government, which seemed to financially compensate traditional elites for their loss of political power. Following the declaration of martial law in 1972, the government began replacing the Datus with government officials from the north. 
Many Datus accepted the state's offer to cooperate and in return for governmental subsidies they abandoned their pro-autonomy stance. Since the traditional ulama was highly dependent on the Datus, they also started to preach accommodation and called for a cessation of hostilities. This collaboration led to a massive loss of reputation within the population. Consequently, rebel leaders convincingly branded traditional elites and their clerics as protagonists of feudal structures and supporters of an imperialist central government. At the same time, the highly educated young religious teachers of the rebel movement were able to effectively shield the rebel movement from rhetorical attacks by traditional religious elites. ${ }^{82}$

Framing contests were much more intense in Thailand. Rebels' religious frames were attacked from two sides. On the one hand, they were competing with 'official Islam.' The Patronage of Islam Act of 1945 established a central religious bureaucracy controlled by the state. While national-level representatives of the official Islam are seen as being co-opted by the government, ${ }^{83}$ local officials are elected. This seeming autonomy of local religious affairs provided functionaries with some religious legitimacy. ${ }^{84}$ Thus, even though they were members of the official Islam, local officials had credibility and could successfully question the rebel organizations' frames. Simultaneously, the rebels' religious frames were attacked by the local Dawah movement. Alongside a general religious renaissance in the mid-twentieth century, reform-oriented Islamic movements gained momentum in Bangkok and spread to the south of the country. ${ }^{85}$ They spoke out against the secularization of Thailand and for the 'cleansing' of the Islamic faith. ${ }^{86}$ Although they supported Muslim autonomy efforts in many areas, they called for peaceful dialog between Muslims and Buddhists. ${ }^{87}$ As students of Arabic schools, members of the Dawah movement were seen as religious experts among the population and their religious judgments were not easily questioned. ${ }^{88}$ Furthermore, the fact that they were funded by local and foreign donations allowed them to act independently. Their call to protect Islam by returning to orthodox values was very effective and persuaded many Muslims to abandon violent activism as propagated by the rebel movements. ${ }^{89}$

\section{CONCLUSION}

Comparative studies on the conflicts in the Philippines and in Thailand ascribe the distinct conflict dynamics to three factors. ${ }^{90}$ First of all, the levels of repression were different. While the Philippine government tried to marginalize, or even eradicate, the Muslim culture in Mindanao, the Thai government was more concerned with the political control of Pattani. Second, the successful economic and administrative reforms carried out by the Thai government significantly reduced the rebel's support base. ${ }^{91}$ Finally, variance in regime types may explain why the conflict in the Philippines escalated while the conflict in Thailand did not. A closer look at these three alternative approaches shows, however, that they do not give the full picture of the diverging conflict dynamics in the Philippines and in Thailand. 
While military repression was more intense in the Philippines than in Thailand, the fundamental economic and political situation was very similar for the Muslim minorities. In both cases, the economy and the administration at the local and the national level were dominated by members of other faiths. ${ }^{92}$ Although Muslims in the Philippines may have been more affected by resettlement programs, the Thai government implemented similar policies designed to undermine the cultural and religious identity of Muslims. ${ }^{93}$

Moreover, the timing of political reforms in Thailand does not fit with the second explanation. The rebels had already lost their ability to mobilize broad support even before the start of the Thai reform policies of the 1980s. Moreover, similar reform attempts were made in the Philippines. In 1976, Marcos passed a number of regulations aiming at reducing the dissatisfaction among the Muslim population: Muslim holidays were added to the list of public holidays, measures to improve infrastructure in the southern region were implemented, an Institute for Islamic Studies was founded, and Muslims were granted additional positions in the government. ${ }^{94}$ Peter Gowing concludes that most of the demands made by moderate Muslim intellectuals had actually been implemented by the end of the 1970 s. ${ }^{95}$

Lastly, a comparison of the development of regime types in both countries would actually suggest that violence should have been more likely and intense in Thailand than in the Philippines. The latter had been a comparably stable autocratic system since the mid-1960s. With the so-called 'People Power Revolution' and President Marcos' fall in 1986, this system was replaced by an equally stable democracy. The political conditions in Thailand were not nearly as constant. Particularly in the 1960s and 1970s, large fluctuations in the Polity IV index can be observed. ${ }^{96}$ Various articles stress the fact that a regime change of this kind should increase the probability of civil war and that armed conflicts are less likely in stable autocratic and democratic regimes. ${ }^{97}$

Political and economic factors certainly affected the conflict dynamics in the Philippines and in Thailand. Our two cases exhibit similar but certainly not identical political and economic contexts. Thus, we cannot categorically deny that these factors' have influence on the two conflicts. Without taking framing processes into account, however, these factors will not be able to convincingly explain the differences between the two cases. What is more, the two cases demonstrate the need for understanding the impact of 'religious identity incompatibilities' and 'religious issue incompatibilities' on the management of political conflicts as dependent on discursive processes of mobilization. In fact, 'religious identity incompatibilities' and 'religious issue incompatibilities' as such seem to be unrelated to conflict onset, conflict intensity or conflict duration. Only if a religious conflict frame resonates with a constituency and only if it is not outperformed by persuasive counter-frames will the mobilization of the faithful into violent action succeed. Further studies are certainly needed before we are able to reliably assess the explanatory power of the framing approach for the escalation of intrastate conflict. Yet, the theoretical explanation and empirical observations in this article suggest that religious framing 
can play an important role in violent conflicts and should not be ignored in conflict analysis.

\section{ACKNOWLEDGEMENTS}

The authors gratefully acknowledge the helpful comments of two anonymous reviewers who did a great job. We also thank the participants of the international workshop on 'Framing Political Violence: A Micro Approach to Civil War Studies' held at the University of Tuebingen/Germany in September 2013 for their critics and suggestions on an earlier version of our paper. This research was supported by the German Peace Research Foundation and the Collaborative Research Center 'Threatened Orders Societies under Stress' funded by the German Research Foundation.

\section{NOTES ON CONTRIBUTORS}

Alexander De Juan is a senior research fellow with the GIGA German Institute of Global and Area Studies. His current main research interests are state building and geographical patterns of violent conflict. His most recent work has appeared in the Journal of Peace Research, Political Geography, and Political Research Quarterly. Email: alexander.dejuan@giga-hamburg.de

Andreas Hasenclever is professor of International Relations and Peace Studies at the Institute for Political Science at the Eberhard Karls University of Tübingen, Germany. His major research interests are in the field of Peace and Conflict studies with particular reference to the analysis of the Democratic Peace, regime analysis, and the impact of religious traditions on political conflicts. Email: andreas. hasenclever@uni-tuebingen.de

\section{NOTES}

1. Samuel P. Huntington, The Clash of Civilizations and the Remaking of World Order (New York: Simon \& Schuster 1996)

2. In line with previous definitions, we use terms such as 'religious civil wars' or 'religious violent conflicts' to refer to violence in between groups belonging to different religions or confessions that is interpreted in religious terms by the conflict actors. As we will argue in this paper, however, this religious dimension of violence does not mean that religion and religious differences constitute main causes of the respective conflicts.

3. Michael E. Brown, 'The Causes of Internal Conflict: An Overview' in Michael E. Brown (ed.) Nationalism and Ethnic Conflict (Cambridge, MA: MIT Press 2001), pp.3 25; Paul Collier, Anke Hoeffler, and Dominic Rohner, 'Beyond Greed and Grievance: Feasibility and Civil War', Oxford Economic Papers 61/1 (2009), pp.1 27.

4. F. Gutiérrez Sanin and Elisabeth Jean Wood, 'Ideology in Civil War: Instrumental Adoption and Beyond', Journal of Peace Research 51/2 (2014), pp.213 26; Kai M. Thaler, 'Ideology and Violence in Civil Wars: Theory and Evidence from Mozambique and Angola', Civil Wars 14/4 (2012), pp.546 67.

5. Ron E. Hassner, "To Halve and to Hold": Conflicts over Sacred Space and the Problem of Indivisibility', Security Studies 12/4 (2003), pp.1 33; Michael C. Horowitz, 'Long Time Going: Religion and the Duration of Crusading', International Security 24/2 (2009), pp.162 193; Mark Juergensmeyer, Global Rebellion: Religious Challenges to the Secular State, from Christian Militias to Al Qaeda (Berkeley, CA: University of California Press 2008); Monica Duffy Toft, 'Getting Religion? The Puzzling Case of Islam and Civil War', International Security 31/4 (2007), pp.97 131.

6. Horowitz (note 5) p.168. 
7. Jonathan Fox, An Introduction to Religion and Politics: Theory and Practice (London: Routledge 2013), pp.84 93.

8. For the importance of the three R Reason, Resolve, Resources for conflict onset and conflict termination, see Thomas Ohlson, 'Understanding Causes of War and Peace', European Journal of International Relations 14/1 (2008), pp.133 60.

9. Jonathan Fox, 'The Religious Wave: Religion and Domestic Conflict from 1960 2009', Civil Wars $14 / 2$ (2012), p.150.

10. Matthias Basedau, Georg Strüver, Johannes Vüllers, and Tim Wegenast, 'Do Religious Factors Impact Armed Conflict? Empirical Evidence From Sub Saharan Africa', Terrorism and Political Violence 23/5 (2011), pp.752 79; Håvard Hegre and Nicholas Sambanis, 'Sensitivity Analysis of Empirical Results on Civil War Onset', Journal of Conflict Resolution 50/4 (2006), pp.508 35.

11. Basedau et al. (note 10) p.767; Jonathan Fox, Religion, Civilization, and Civil War: 1945 Through the Millennium (Lanham, MD: Lexington Books 2004), pp.71 7.

12. Nils Christian Bormann, Lars Erik Cederman, and Manuel Vogt, 'Ethnonationalist Cleavages in Civil Wars: Allah's Wrath or Babel's Legacy?' (Zürich: National Centre of Competence in Research Challenges to Democracy in the 21st Century, Working Paper No. 58).

13. Uwe Wagschal, Aurel Croissant, Thomas Metz, Christoph Trinn, and Nicolas Schwank, 'Kulturkonflikte in inner und zwischenstaatlicher Perspektive', Zeitschrift für Internationale Beziehungen 17/1 (2010), pp.7 39.

14. Joshua R. Gubler and Joel Sawat Selway, 'Horizontal Inequality, Crosscutting Cleavages, and Civil War', Journal of Conflict Resolution 56/2 (2012), pp.206 32.

15. Fox (note 11) p.46; Toft (note 5) p.116. The study of Monica Toft is particularly puzzling. On the one hand, she claims that 'religious wars are much more destructive than wars fought over other issues: They result in more casualties and more noncombatant deaths.' Here, concrete findings, however, point to the opposite: Monica Toft reports 28.000 so called average civilian deaths per year for civil wars in which religion was a central issue. In nonreligious civil wars, the average annual civilian death toll was 43.000! (Toft (note 5) p.116f, fn. 53).

16. Ragnhild Nordås, Are Religious Conflicts Bloodier? Assessing the Impact of Religion on Civil Conflict Casualties, Paper prepared for the International Studies Association (ISA) 48th Annual Convention, Chicago, Illinois, 28 Feb. 3 Mar. 2007; Bethany A. Lacina, 'Explaining the Severity of Civil Wars', Journal of Conflict Resolution 50/2 (2006), pp.276 89.

17. Susanna Pearce, 'Religious Rage: A Quantitative Analysis of the Intensity of Religious Conflicts', Terrorism and Political Violence 17/3 (2005), pp.333 52.

18. Frances Stewart, Religion Versus Ethnicity as a Source of Mobilisation: Are There Differences? (Oxford: CRISE, Working Paper 70, 2009), p.28.

19. Toft (note 5) p.116.

20. Tanja Ellingsen, 'Toward a Revival of Religion and Religious Clashes?', Terrorism and Political Violence 17/3 (2005), pp.318 9.

21. Andrej Tusicisny, 'Civilizational Conflicts: More Frequent, Longer, and Bloodier?', Journal of Peace Research 41/4 (2004), p.494.

22. Paul Collier, Anke Hoeffler, and Måns Södernbom, 'On the Duration of Civil War', Journal of Peace Research 14/3 (2004), p.266.

23. Isak Svensson, 'Fighting with Faith. Religion and Conflict Resolution in Civil Wars', Journal of Conflict Resolution 51/6 (2007), pp.930 49.

24. Svensson (note 23) p.944.

25. Isak Svensson, Ending Holy Wars. Religion and Conflict Resolution in Civil Wars (Queensland: University of Queensland Press 2010); Isak Svensson and Emily Harding, 'How Holy Wars End: Exploring the Termination Patterns of Conflicts with Religious Dimensions in Asia', Terrorism and Political Violence 23/2 (2011), pp.133 49.

26. R. Scott Appleby, The Ambivalence of the Sacred: Religion, Violence, and Reconciliation (Lanham, MD: Rowman \& Littlefield 2000), p.61

27. Robert D. Benford and David A. Snow, 'Framing Processes and Social Movements: An Overview and Assessment', Annual Review of Sociology 26/3 (2000), p.614.

28. Alexander De Juan, 'The Role of Intra Religious Conflicts in Intrastate Wars', Terrorism and Political Violence, online first, May 2014; Colin Barker, Alan Johnson, and Michael Lavalette, 'Leadership Matters: An Introduction' in Colin Barker et al. (eds.) Leadership and Social Movements (Manchester: Manchester University Press 2001) pp.1 23. 
29. Appleby (note 26), p.61; Hans G. Kippenberg, Gewalt als Gottesdienst: Religionskriege im Zeitalter der Globalisierung (München: Beck 2008); Jeffrey R. Seul, “Ours is the Way of God": Religion, Identity, And Intergroup Conflict', Journal of Peace Research 36/5 (1999), p.565.

30. David A. Snow and Scott C. Byrd, 'Ideology, Framing Processes, and Islamic Terrorist Movements', Mobilization 12/2 (2007), pp.119 36; Douglas Johnston and Brian Cox, 'Faith Based Diplomacy and Preventive Engagement' in Douglas Johnston (ed.) Faith Based Diplomacy: Trumping Realpolitik (Oxford: Oxford University Press 2003) p.14.

31. Benford and Snow (note 27) p.619 22; John A. Noakes and Hank Johnston, 'Frames of Protest: A Road Map to a Perspective' in Hank Johnston and John A. Noakes (eds) Frames of Protest: Social Movements and the Framing Perspective (Lanham, MD: Rowman \& Littlefield Publishers 2005) pp.11 16.

32. Seul (note 29) p.563.

33. Benford and Snow (note 27) p.626; Noakes and Johnston (note 31) p.13.

34. Quintan Wiktorowicz, 'Framing Jihad: Intramovement Framing Contests and al Qaeda's Struggle for Sacred Authority', International Review of Social History 49/S12 (2004), pp.167 8.

35. Johnston and Cox (note 30) p.14.

36. Brent Hierman, 'The Pacification of Xinjiang. Uighur Protest and the Chinese State, 1988 2002', Problems of Post Communism 54/3 (2007), pp.48 62.

37. Alexander De Juan, 'A Pact with the Devil? Elite Alliances as Bases of Violent Religious Conflicts', Studies in Conflict and Terrorism 31/12 (2009), pp.1120 35.

38. Rachel L. Einwohner, 'Leadership, Authority, and Collective Action: Jewish Resistance in the Ghettos of Warsaw and Vilna', American Behavioral Scientist 50/10 (2007), pp.1306 26.

39. Alexander De Juan, Innerstaatliche Gewaltkonflikte unter dem Banner der Religion (Baden Baden: Nomos 2010).

40. Wiktorowicz (note 34).

41. Juergensmeyer (note 5); Toft (note 5).

42. Lawrence Cline, 'The Islamic Insurgency in the Philippines', Small Wars \& Insurgencies 11/3 (2000), pp.115 38; Peter Kreuzer and Mirjam Weiberg, Zwischen Bürgerkrieg und friedlicher Koexistenz: Interethnische Konfliktbearbeitung in den Philippinen, Sri Lanka und Malaysia (Bielefeld: Transcript 2007).

43. Duncan McCargo, Tearing Apart the Land: Islam and Legitimacy in Southern Thailand (Ithaca, NY: Cornell University Press 2008).

44. Andrew D.W. Forbes, 'Thailand's Muslim Minorities: Assimilation, Secession, or Coexistence?', Asian Survey 22/11 (1982), pp.1056 73; Neil J. Melvin, Conflict in Southern Thailand. Islamism, Violence and the State in the Patani Insurgency (Stockholm: SIPRI, Policy Paper 20, 2007).

45. It was only in 2001 that Thaksin Shinawatra was elected Prime Minister and elements of the old assimilation policy were resurrected, thereby jump starting the rebellion. It remains unclear whether or not the original groups are behind the recent violence (International Crisis Group, Southern Thailand: Insurgency, Not Jihad Brussels 18 May 2005); Melvin (note 44) p.16.

46. Cesar Adib Majul, The Contemporary Muslim Movement in the Philippines (Berkeley, CA: Mizan Press 1985) p.903; Moshe Yegar, Between Integration and Secession: The Muslim Communities of the Southern Philippines, Southern Thailand, and Western Burma/Myanmar (Lanham, MD: Lexington Books 2002) pp.251 3.

47. Thomas M. McKenna, 'Saints, Scholars and the Idealized Past in Philippine Muslim Separatism', The Pacific Review 15/4 (2002), pp.539 53, 45; Jan Stark, 'Muslims in the Philippines', Journal of Muslim Minority Affairs 23/1 (2003), p.201; Yegar (note 46) pp.277 8.

48. McKenna (note 47) p.545.

49. Cited after Thomas M. McKenna, Muslim Rulers and Rebels: Everyday politics and Amed Separatism in the Southern Philippines (Berkeley, CA: University of California Press 1998) p.208.

50. Salamat 1985 as cited by Joseph Chinyong Liow, Muslim Resistance in Southern Thailand and Southern Philippines: Religion, Ideology, and Politics (Washington, DC: East West Center 2006) p.16.

51. Wan Kadir Che Man, Muslim Separatism: The Moros in Southern Philippines and the Malays in Southern Thailand (Oxford, NY: Oxford University Press 1990), p.98; S.P. Harish, 'Ethnic or Religious Cleavage? Investigating the Nature of the Conflict in Southern Thailand', Contemporary Southeast Asia: A Journal of International and Strategic Affairs 28/1 (2006), pp.51 4.

52. Che Man (note 51) pp.101, 112; Harish (note 51) p.54. 
53. Chaiwat Satha Anand, Islam and Violence: A Case Study of Violent Events in the Four Southern Provinces, Thailand, 19761981 (Tampa, FL: Department of Religious Studies, University of South Florida 1987).

54. PULO 12/06/1997 in Satha Anand (note 53) p.32.

55. Satha Anand (note 53) pp.32 4.

56. McKenna (note 49) p.157.

57. Che Man (note 51); Cline (note 42); McKenna (note 49).

58. Majul (note 46) pp.79 80; Yegar (note 46) pp.278 279.

59. McKenna (note 49) p.196.

60. Cline (note 42) p.132.

61. Che Man (note 51) p.84; Eric U. Gutierrez, ed., Rebels, Warlords, and Ulama: A Reader on Muslim Separatism and the War in Southern Philippines (Quezon City: Institute for Popular Democracy 2000) pp.146 61.

62. Cline (note 42); McKenna (note 49).

63. Harish (note 51) p.58.

64. International Crisis Group (note 45) p.13

65. International Crisis Group (note 45) p.9.

66. Astri Suhrke, 'Loyalists and Separatists: The Muslims in Southern Thailand', Asian Survey 17/3 (1977), pp.241 2.

67. Exact CAMEO codes used for creating this subset are available upon request. Provinces included for Thailand are Narathiwat, Pattani, Satun, Songkhla, and Yala. Provinces included for the Philippines are Basilan, Lanao del Sur, Maguindanao, Sulu, and Tawi Tawi.

68. McKenna (note 49); Majul (note 46).

69. Gutierrez (note 61) p.155.

70. McKenna (note 49) p.184.

71. Stark (note 47) p.201; Yegar (note 46) pp.277 8, 06; Eric U. Gutierrez and Abdulwahab Guialal, 'The Unfinished Jihad: The Moro Islamic Liberation Front and Peace in Mindanao' in Gutierrez (note 61), p.277.

72. Stark (note 47) p.206; Gutierrez and Guiala (note 71) p.277.

73. Che Man (note 51); Michel Gilquin, Les musulmans de Thaïlande (Paris, Bangkok: Harmattan, IRASEC 2002).

74. Kamal M. Hassan, 'Some Dimensions of Islamic Education in South East Asia' in Taufik Abdullah and Sharonv Siddique (eds) Islam and Society in Southeast Asia (Singapore: Institute of Southeast Asian Studies 1986), p.45.

75. Satha Anand (note 53)

76. Liow (note 50) p.13; McKenna (note 49) p.232.

77. Gutierrez (note 61) p.157; Liow (note 50) p.14.

78. Gutierrez and Guiala (note 71) p.282.

79. Che Man (note 51) p.108.

80. Harish (note 51).

81. Che Man (note 51).

82. McKenna (note 49) p.138; Stark (note 47) p.206; Kreuzer and Weiberg (note 42) p.195

83. Satha Anand (note 53) p.23; Wattana Sugunnasil, 'Radicalism, and Violence in Southern Thailand. Berjihad die Patani and the 28 April 2004 Attacks' in Duncan McCargo (ed.) Rethinking Thailand's Southern Violence (Singapore: NUS Press 2007) pp.129 31.

84. Omar Farouk, 'The Muslims of Thailand: A Survey' in Andrew D.W. Forbes and Sachchidanand Sahai (eds) The Muslims of Thailand (Bihar: Centre for South East Asian Studies 1989) p.19.

85. Raymond Scupin, 'Muslim Accommodation in Thai Society', Journal of Islamic Studies 9/2 (1998), pp.229 58; Imtiyaz Yusuf, Faces of Islam in Southern Thailand (Washington, DC: East West Center, Working Papers 7, 2007).

86. Surin Pitsuwan, Islam and Malay Nationalism: A Case Study of the Malay Muslims of Southern Thailand (Bangkok: Thai Khadi Research Institute, Thammasat University 1985) pp.248 9.

87. Scupin (note 85) pp.254 5; Yusuf (note 85) p.12.

88. Ruth McVey, 'Identity and Rebellion Among Southern Thai Muslims' in Andrew D.W. Forbes and Sachchidanand Sahai (eds) The Muslims of Thailand (Bihar: Centre for South East Asian Studies 1989) p.47.

89. Scupin (note 85$)$ p.255. 
90. Che Man (note 51); Liow (note 50); Peter Chalk, 'Separatism and Southeast Asia: The Islamic Factor in Southern Thailand, Mindanao, and Aceh', Studies in Conflict \& Terrorism 24/4 (2001), pp.241 69; Yegar (note 46).

91. Chalk (note 90) p.258; Liow (note 50); Che Man (note 51) p.115.

92. Forbes (note 44); Suhrke (note 66); Yegar (note 46) p.126.

93. M. Ladd Thomas, 'The Thai Muslims' in Raphael Israeli (ed.) The Crescent in the East: Islam in Asia Major (London, Atlantic Highlands, NJ: Curzon Press, Humanities Press 1989) p.160f; Forbes (note 44) p.1059; International Crisis Group (note 45) p.3.

94. Majul (note 46) pp.79 80; Yegar (note 46) pp.2789.

95. Peter G. Gowing, Muslim Filipinos (Quezon City: New Day Publishers 1979), p.224.

96. See the data as provided by the Polity IV Project: Regime Characteristics and Transitions, 1800 2013. Available online under http://www.systemicpeace.org/polity/polity4.htm (last retrieved August 2015).

97. Havard Hegre, Ranveig Gissinger, Nils Petter Gleditsch, 'Globalization and Internal Conflict' in Gerald Schneider, Katharine Barbieri, Nils Petter Gleditsch (eds) Globalization and Armed Conflict (Lanham, MD: Rowman \& Littlefield 2003) pp.251 75. 